\title{
Competing Ways of Life: Islamism, Secularism, and Public Order in the Tunisian Transition
}

\section{Citation}

Zeghal, Malika. 2013. Competing Ways of Life: Islamism, Secularism, and Public Order in the Tunisian Transition. Constellations 20, no. 2: 254-274.

\section{Published Version}

doi:10.1111/cons. 12038

\section{Permanent link}

http://nrs.harvard.edu/urn-3:HUL.InstRepos:12724047

\section{Terms of Use}

This article was downloaded from Harvard University's DASH repository, and is made available under the terms and conditions applicable to Open Access Policy Articles, as set forth at http:// nrs.harvard.edu/urn-3:HUL.InstRepos:dash.current.terms-of-use\#OAP

\section{Share Your Story}

The Harvard community has made this article openly available.

Please share how this access benefits you. Submit a story.

\section{Accessibility}




\section{Competing Ways of Life:}

\section{Islamism, Secularism, and Public Order in the Tunisian Transition}

\section{Malika Zeghal}

The Tunisian uprisings ${ }^{1}$ of $2010-2011$ constituted a moment that can be described as "fugitive democracy," a term coined by Sheldon Wolin to describe ephemeral and exceptional moments of commonality that contrast with fractioned everyday institutionalized politics. In the context of "fugitive democracy," "a free society composed of diversities can nonetheless enjoy moments of commonality when, through public deliberations, collective power is used to promote or protect the well-being of the collectivity." "2 Between the self-immolation of Mohamed Bouazizi on December 17, 2010, and the departure of President Ben Ali on January 14, 2011, Tunisians experienced such a political moment: the usual boundaries separating those excluded from political institutions from those included in them disappeared. It was precisely during this moment-comparable to a tabula rasa-that it became possible for demonstrators all over Tunisia to readily demand and imagine the possibility of an entirely new political system. This desire for radical change was illustrated by the slogan declaimed by the protestors on January 14, 2011, the day Ben Ali fled: "the people want to bring down the regime" (al-sha 'b yurid isqat al-nizam). It could also be heard in the now famous imperative "Dégage!,"3 addressed in French to the president and to the police in front of the building of the feared ministry of Interior on the main avenue of the capital.

During the uprisings, protesters did not represent the future as 'Islamic' or 'secular.' They simply saw it as reconfigurable, for the sudden absence of institutionalized politics made it 
ripe for radical change, allowing unification around the demand for a total rupture with the past. The religious/secular dichotomy, although an ordinary staple in the political narratives of authoritarian politics, did not help Tunisians articulate their political demands, chiefly the departure of their dictator and the end of his regime. They saw themselves as one "people" endowed with agency, as expressed in "the people want" (al-sha 'b yurid) ${ }^{4}$ Once the president fled, as if obeying at once the order of the people, this exceptional and extraordinary moment ended and with it fugitive democracy.

After the departure of the President, a second phase followed. Institutional differences reemerged and, for many Tunisians, the extraordinary moment of fugitive democracy became a thawra (revolution), only reasserting itself through nostalgia or celebration. For some, the revolution had been stolen, as recounted to me by a young Tunisian who had demonstrated against Ben Ali's regime during the protests: "in the end, the revolution failed. They [the political parties] used us, they used the story of the revolution." ${ }^{, 5}$ For others, such as political parties and state representatives, it was time to speak and act "in the name of the revolution." The uprisings, because of their success, were memorialized in all sorts of images and narratives, inside and outside the state administration. As early as March 2011, postal stamps were commemorating the thawra. Its memory remained utterly present and operated as the foundational event of a new era of politics. It allowed a distinction in the history of Tunisia between the time "before" and the time "after the revolution." In this second phase, anxious interrogations about the place and role of Islam and secularism in Tunisia took over the newly opened and variegated field of political competition. Tunisians were projecting the question of Islam back into the analysis of the nature of the massive movement that created a political rupture, even if to insist on the fact that it was not an "Islamic revolution." As Ajmi Lourimi, a 
member of the political bureau of the Islamist party al-Nahdha told me in the summer of 2011: "This was not an Islamic revolution. It was a nationalist and popular revolution (thawra wataniyya wa sha 'biyya). Of course it was not devoid of questions related to identity. But it was a secular revolution (thawra 'ilmaniyya) that did not take place against Islam."7 This overwhelming re-entry of "Islam" and "secularism" into the arena of electoral politics and of deliberative public expressions turned out to be complicated by the history of these concepts within Tunisia before the uprisings. Under the authoritarian regimes of Presidents Bourguiba and Ben Ali, the public interpretations of Islam and of the attendant concept of secularism were essentially defined and authorized by the state. The state administration tightly regulated and controlled Islamic institutions and narratives, those men and women who articulated them, as well as what it deemed to be "correct" Muslim practices in a "modern" Tunisia. After the departure of Ben Ali, in a context of expanded freedoms of expression in the public space and of a weakened central authority, narratives about Islam and secularism multiplied and served as differentiation devices in the political arena. Tunisians who referred to Islam as a normative element of social life and politics demanded the liberation of the discourses on Islam and of the religious institutions from the state's control, such as mosques, religious schools, and fatwas. ${ }^{8}$ They also wanted to impose limits on what they considered to be non-Islamic behaviors. Those who referred to the idea of a Tunisia they wanted to be "secular" or "modern," demanded the liberation of expression in almost all its forms, but often wanted to impose limits on some expressions of Islam they deemed dangerous or incorrect. For both sides, the content and limits of the newly acquired freedom needed to be defined. New battle lines were drawn that had less to do with the pitting of the pro "Islamic state" camp versus the pro "democratic-secular state" forces-as they were often described by the actors themselves-than with different conceptions of 
freedom (hurriyya) and of its content and limits. It is worth noting that, unlike the secular versus Islamic state debate, freedom was a concept conspicuously present in the 2010-2011 protests, for instance in the slogan "Work, freedom, national dignity" (shughl, hurriyya, karama wataniyya).

What did freedom mean for Tunisians after the departure of Ben Ali? Should it be allowed to say and do anything? In other words what are the limits to one's exercise of freedom and how are these limits defined? I argue that these questions on the meaning of freedom that proliferated in the public arena in combination with those on Islam and secularism, were less about the form of the political regime-there was a consensus among Tunisians that it should be a republican electoral democracy-than about the "ways of life" of Tunisians. The Tunisian political transition can help examine how conceptions of "ways of life," that is, the understanding of correct beliefs and conduct, translate into and shape politics. Political ideologies neither made themselves visible in the uprisings, nor emerged as important forces shaping the dynamics of the transition. "This revolution was mute, it did not articulate an ideological project," $"$ a Tunisian professor of philosophy commented to me in June 2011. This diagnosis was echoed by a secondary school teacher who interpreted the uprisings as "a revolution of bodies, not minds." 10 "The youth have projects, but they are personal projects," a member of the Maghrebi Liberal Party also told me. ${ }^{11}$ I contend that this is the case because after January 14, 2011, rather than fight for specific ideological systems and for these ideologies' specific understandings of the state, Tunisian political elites cared, debated, and fought about safeguarding their individual ways of life and about the attendant conception of freedom they imagined.

In order to delve into the new politics of post-Ben Ali Tunisia, a politics devoid of ideological projects but animated by convictions about how one ought to live, I start this essay 
with an explanation of the nature of the Tunisian protests. An uprising stemming from an economic crisis and deep regional economic inequalities at first, it rapidly became political, leading to the fall of the President of the Republic and to the expansion of freedom of expression. In spite of the prevailing dire economic problems, the public political discussions during the transition period that followed focused on the meaning of "Islamism" and "secularism," as they related to definitions of ways of life. I examine these discussions by focusing mainly on the Islamist party al-Nahdha and its conceptions of "secularism." I show that like most other parties, it supported the idea of an electoral democracy combined with a religious establishment. Although the project of electoral democracy was one that contrasted with the practices of the previous regime, the notion of a religious establishment molded itself into its institutions. I argue that Islamist and secularist intellectuals and activists, taking advantage of the new freedoms of expression, competed on their different conceptions of ways of life, whereas a status quo was maintained on an institutional relationship between state and religion that enabled the formulation of limits to freedoms. I end this essay by showing how the notion of "public order" was invoked in several legal affairs in post-Ben Ali Tunisia to outline the content and limits of individual freedoms, in continuity with the previous authoritarian regime. The fear of chaos spurred by religious confrontations brought back the state into being the institution maintaining

order, an order called for by Islamists and secularists alike to put limits to the new freedoms and safeguard each camp's ways of life.

\section{From Economics to Politics: The Collapse of Two Myths}

The Collapse of the Myth of the Tunisian "Economic Miracle" 
The uprisings that started in late 2010 in Sidi Bouzid, Tunisia, opened up a new political era. In post-colonial Tunisia, and more largely in post-colonial North Africa, popular protests were not a new phenomenon. Dubbed the "bread revolts," they had punctuated social and economic life since the 1960s, but had never led to regime change. ${ }^{12}$ In 2011, however, a strong and massive popular mobilization succeeded in beheading the state and opened up a transitional period that led to free elections for a Constituent Assembly and a new interim government. In Tunisia, as in Egypt and Libya, the success of these protests in toppling the heads of the regimes indicated that any type of negotiated or "pacted" transition had failed and that it took the force of popular mobilization in the streets to produce political change: these regimes were not able, contrary to what many observers and analysts were expecting, to reform from within. ${ }^{13}$ The traditional political opposition itself was not at the origin of these uprisings. The popular protests were not led by the traditional legal and illegal opposition groups, who were in fact surprised by the course of these extraordinary events. In addition, not only did political change originate from outside the regime itself and from outside the sphere of the traditional opposition: it originated from outside the political field tout court. It was the economic crisis that precipitated the Tunisian protests. As if politics could not take care of itself, the economic crisis became the force behind political change. In the decade that ended in 2008, the Tunisian economy grew at an annual rate of about $5 \%$, leading international observers as well as the regime itself to speak of a "Tunisian economic miracle." ${ }^{14}$ But after the financial crisis of 2008, with the contraction of the global economy, especially in Europe, which is the main export market for Tunisia, growth weakened. This made the economic situation fragile. Between 2007 and 2010, Tunisia's GDP annual growth rate decreased from $6.3 \%$ to $3.7 \% .{ }^{15}$ During the same period, indicators of well being also decreased, ${ }^{16}$ leading an increasing number of young Tunisians to attempt to migrate 
legally or illegally to Europe. ${ }^{17}$ In 2008 , unemployment rates reached $13 \%$ on average but were $30 \%$ for the youth (15-24 years). ${ }^{18}$ In the 1990s, the World Bank had hailed Tunisian economic reforms as successful but had neglected the significance of growing inequalities. The nature of the 2010-2011 protests were what made the World Bank recognize the necessity of taking into account social exclusion and economic inequalities in its evaluations. ${ }^{19}$ In the center regions of Tunisia, such as Kasserine and Sidi Bouzid, the cradle of the 2010-2011 uprisings, increasing inequalities and social exclusion were at the source of the uprisings. ${ }^{20}$ After the departure of Ben Ali, the myth of the "economic miracle," which had been cultivated by the regime, fell apart.

\section{An Uprising against Social Exclusion Turned Political}

This is not to say that the uprisings had no political significance. In Tunisia, week after week, as new towns and cities joined in the protests, progressively reaching Tunis, the capital, the demonstrations became endowed with clear political meaning. They carried a strong moral condemnation of the regime. Indeed, the self-immolation of Bouazizi, ${ }^{21}$ rather than being interpreted as another sign of the suffering of the disinherited youth, was recounted by political activists as a political assassination: the state was the real culprit of Bouazizi's death because it had failed to respond to his requests for help. ${ }^{22}$ The absence of ideological slogans inspired by the intellectual traditions of the opposition was striking. Shughl, hurriyya, karama wataniyya (Work, freedom, national dignity) was one of the most repeated slogans early in the protests. The notion of dignity (karama) was central in the narratives of the protests, which denounced the economic and political humiliation that Tunisians experienced daily under the authoritarian regime. National dignity was understood to proceed from the first two items evoked in the slogan: work and freedom. Unlike during the nationalist struggle against French occupation, 
national dignity was not to proceed from gaining independence from the foreigner. This time, the collective sense of belonging to one's nation would proceed from individual rights of access to economic opportunities. The people's demands were focused on their material conditions of life. However, these demands also expressed a desire for a new type of relationship between Tunisians and their state. The demand for economic access was deeply linked to a demand for access to citizenship. Tunisians wanted to be recognized as citizens instead of being treated as subjects. A few days before January 14, 2011 the blend of economic and political demands gave way to a new slogan: "The people want to topple the regime" (al-sha'b yurid isqat al-nizam). From its economic and moral origins, the movement became clearly political. In the Tunisian and international media, the uprisings were interpreted as a "secular revolution," whose actors had asserted universal values.

\section{The Collapse of the Myth of Secular Tunisia}

After the departure of President Ben Ali, a new political chapter in the history of Tunisia started: a political transition in which competitive electoral politics played a central role as the pressure of street politics progressively waned, in spite of episodic flare ups, for the next few months. This second phase led to the legalization of political parties: more than 100 of them competed for the electors' votes. This marked a strong break with the previous 55 years of post-colonial politics in Tunisia, during which no election was held in a fair and free context and the opposition was either co-opted and considerably weakened or brutally repressed. Among these political parties stood those that had traditionally shaped the Tunisian political landscape: from the old communist party to the center left political groups and the Islamist movement al-Nahdha. In this newly opened political game, the Islamist party, authorized in March 2011 for the first 
time, became the object of heated controversies. What was to become of "secular" and "modernist" Tunisia if al-Nahdha won the election? This question haunted most of Tunisian elites as well as many international observers. It took a more urgent turn when the election results were announced. The Islamist party obtained the highest number of seats in the Constituent Assembly, winning 89 seats out of a total of 217, way ahead of two center-left political parties, the Congrès pour la République (CPR) (29 seats) and Ettakatol (21 seats, the Arabic acronym for the Democratic Forum for Labor and Liberties). An independent list, al'aridha al-sha biyya (The Popular Petition), obtained 26 seats. This electoral result highlighted al-Nahdha's popularity and deeply shattered the Tunisian political landscape, from which it had been excluded since the creation of its movement in 1981. As had happened with the image of an economically successful Tunisia, the myth of a "secular" and “modern” Tunisia fell apart.

It was striking that in spite of the daunting economic problems that Tunisia was facing at the time, the public debates during and after the electoral campaign did not focus mainly on economic policy or social questions, but rather on the future role of the Islamist party and on the place of religion in politics. Although it was often repeated during and in the immediate aftermath of Ben Ali's fall that the Tunisian uprisings were not founded on religious demands and would not lead to an "Islamic revolution,"23 Islam and its place in society and politics haunted the public discussions. This "discursive explosion," 24 to borrow a phrase from Michel Foucault, merits an examination. Indeed, it seemed that Islam as a political concept was simultaneously repressed by a desire to marginalize its political significance and persistently brought up as an object of public interest ${ }^{25}$. 
To understand this paradox, it is necessary to examine the history of the Tunisian Islamist movement's ideas and political behavior, since its ideology and strategic intentions were at the center of the debates animating Tunisian transitional politics.

\section{The Tunisian Islamist Movement, Modernity, and Secularism}

The Tunisian Islamist movement started to take shape at the end of the 1960s, first as an apolitical trend influenced by the Pakistani Jama'at al-Tabligh, which was active in Tunisia at that time. In the beginning, the movement only focused on seeking to bring Tunisians back to Islamic practices and morals, and was not interested in politics. In the mid 1970s, however, the movement politicized and took advantage of the riots of January 1978 to exert its influence on the student movement and on the UGTT (Union Générale Tunisienne du Travail), the strong workers trade union. It was established in 1981 under the name of the Islamic Trend Movement and became "al-Nahdha" (renaissance) in 1988, one year after Ben Ali took over, with the hope that a less religious name would allow it to be legally authorized. However, it was not legalized as a political party until March 2011, two months after Ben Ali's fall. Before the October 23, 2011 election, its members were never authorized to participate in electoral politics, except as independent candidates in the 1989 legislative election. Its legalization into a political party in 2011 allowed it to vie for votes in the newly opened competitive electoral market. Well organized from its inception, it became a mass movement in the 1970 s and the 1980 s, in contrast with all the other political parties of the opposition that were not able to mobilize popular masses around their ideas. It was brutally repressed in the $1990 \mathrm{~s}$ and in the first decade of the $21^{\text {st }}$ century, but it remained popular. Other parties were unable to secure a comparable position in the election of October 23,2011 , in part because they were unable to unite under a single banner 
and in part because al-Nahdha benefited from its legitimacy as a movement that was particularly victimized by the authoritarian regime and could unite around the leadership of Rached Ghannouchi.

\section{Al-Nahdha's Political Thought and the Question of Democracy}

How can we define or summarize the political thought at the foundation of the ideology of the alNahdha party? It is simply impossible to respond to this question because its ideology is not based on a systematic theoretical edifice about politics or about the state more particularly. In other words, al-Nahdha's ideology is not based on a systematic and coherent theory that can be reconstructed through the reading of its founder, Rached Ghannouchi. It is not possible to outline with precision the polity that Ghannouchi imagines. His writings are not meant to provide a political theory, but are rather responses to questions raised by contextual politics. This is in particular true for its stance on the question of democracy and for its definition-or lack thereofof the Islamic state. In the past, al-Nahdha's official ideology did not openly and publicly espouse arguments in favor of the use of violence, although the movement was thought to be associated with violent attacks in Tunisia. ${ }^{26}$ The founding document of the Tunisian Islamist movement included democracy as a recognized principle. Early in the 1980s, Rached Ghannouchi wrote that democracy was a necessity for Tunisian political life, but did not develop a reflection on the relation between democracy and Islam or if and how an Islamic state could be democratic. $^{27}$ Among Al-Nahdha's leaders, some might also have envisioned the possibility of operating in a non-democratic context in which they might have shared power within the incumbent regime. As for Ghannouchi, in the mid 1980s, the efforts of the Islamist movements had to be focused on survival rather than on theoretical and programmatic thoughts. ${ }^{28}$ However, 
while in exile in London after 1989, Ghannouchi had the opportunity to elaborate further on the question of democracy and Islam, and to insist on his commitment to democracy. ${ }^{29}$ The 2011 political transition gave al-Nahdha the opportunity to test this commitment and put it into practice, creating a tension between the theoretical combination of Islam and democracy and the practice of democracy.

This shift towards more attention to democracy by al-Nahdha was not unique in the Tunisian political landscape. Until January 14, 2011, the majority of the opposition experienced political life through cooptation and exclusion, rather than through the ballot box. Most of the political opposition, from left to right, only started to envision democracy and the principles of human rights as a crucial component of political life in the 1980s and 1990s. As Moncef Marzouki, head of the center-left CPR, who became interim president in 2011, said, "I became truly conscious of living under a dictatorship when I returned from France [to Tunisia] in 1978... When I was in France, I did not care about democracy. I was part of a socialist trend. I had even gone to China... I was deeply indifferent to the question of democracy. I considered it a cultural oddity. It was only when I eventually went back to Tunisia that I started thinking about that question." ${ }^{30}$ The evolution of the al-Nahdha movement towards a commitment to democracy is therefore not unique, but rather a feature of most political opposition groups since the end of the 1970s in Tunisia.

In the 2000s, al-Nahdha also decided on a political rapprochement with non-Islamist opposition parties and groups that were now committed to democracy and were also repressed by the regime. Part of the Tunisian left and the Islamists of al-Nahdha rallied together to demand more freedoms from Ben Ali's regime, forming the October 18, 2005 movement in favor of what they called "a minimum wage of democracy." ${ }^{31}$ In interaction with other groups, the Islamist 
movement's leaders insisted on democratic commitment. ${ }^{32}$ Al-Nahdha's more recent narratives, as they emerge from the writings and pronouncements of its leaders in the decade that preceded the 2010-11 uprisings, ${ }^{33}$ indicate a deep engagement of the Tunisian Islamist project with the concepts at the heart of liberal democracy. This combination of democracy and Islam was based on the adherence to the principles of electoral democracy on the one hand and on Islamic law being understood as the result of democratic legislation rather than originating from divine commands on the other hand. ${ }^{34}$ Al-Nahdha's emphasis on democracy was also accompanied by a desire to keep established religion at the heart of the polity, in continuity with the regimes of Bourguiba and Ben Ali. This allowed the movement to speak of the state as a "civil state" (dawla madaniyya) that was nonetheless the guardian and the regulator of Islam and to keep Islam-and conservative moral values-at the center of politics. In that sense, al-Nahdha's conception of the relationship between state and religion did not differ much from the way in which the previous post-colonial regimes had organized it. On the other hand, at the level of its strategic and political behavior as a political party it strived to behave democratically, in accordance with its official declarations of commitment to democracy. This is where it differentiated itself from the previous regimes.

"Its Religion is Islam": Debates and Agreements about Article 1 of the Constitution The position taken by the leadership of al-Nahdha on Article 1 of the Constitution illustrates the convergence between the Islamist party's conception of the relationship between state and religion and the legal structures of the old state in this regard. After the departure of President Ben Ali, the 1959 Constitution was suspended and the interim government decided, under the pressure of constant demonstrations in the street, the election of a Constituent Assembly. New 
debates surrounding Article 1 of the 1959 Tunisian constitution emerged. Article 1 states, "Tunisia is a free and sovereign state, its language is Arabic, its religion is Islam, and its regime is the Republic." What was to become of this article in the new constitution drafting process? Intense debates about its meaning showed that Tunisians gave it different interpretations ranging from the definition of the people's identity, to the principles of sharia being at the foundation of the state. However, during the electoral campaign and even more so after the elections of October 23, 2011, it was rare to find a political party that was ready to raise objections against the inclusion of this article in the future constitution. This was because its absence would produce heated disagreements whereas its presence could satisfy all types of interpretations, since it could be read in different ways. Article 1 could be accepted by all precisely because it had different meanings for different constituencies, without these differences being explicit in its formulation. When asked about Article 1 in the summer of 2011, a former minister in Bourguiba's regime told me, "it is entirely legitimate to write that the state's religion is Islam in the Constitution. It does not matter, because it does not mean anything. You can also add that the state has two feet and two hands, it does not make a difference. ${ }^{35}$ In his view, this was a symbolic formulation made to appease the partisans of the Islamic identity of Tunisia. Those who invoked a secular Tunisia were ready to accept this formulation as the line beyond which they would not go. "We thought we should work on a minimum consensus and defend modern Tunisia, unite on the values of human rights and liberty of conscience. It is true that we also said that we agree to keep article one of the constitution as the maximum acceptable. We are ourselves talking about the religion of Tunisia, and not about the religion of the state, but this ambiguity was intentional on Bourguiba's part," a representative of the Pôle Démocratique Moderniste (al-Qutb al-dimuqrati al-hadathi), the left coalition of parties most in agreement 
with the values of secularism, told me. ${ }^{36}$ When I asked a member of the political bureau of alNahdha about the meaning of Article 1, he also responded that it was a matter of identity, no less no more, and refused to elaborate further on the meaning of a "state's religion" except for saying that the state should not "control" religion but rather "organize it.",37

\section{Rached Ghannouchi, Secularism, and Religious Establishment:}

In his books and articles, Rached Ghannouchi, the Islamist party al-Nahdha's leader and main ideologue, engages with the question of the state and its relation with Islam. In particular, he often associates secularism ('ilmaniyya) with authoritarianism and modernity (hadatha). In an article published in 2011, he criticized the "secularist project" and defined it as "the marginalization of religion and its estrangement from the struggles of life." ${ }^{38}$ In his view, the task of the Islamist movement is to "reestablish the relationship between religion and life and the leadership of religion over life." 39 For Ghannouchi, "modernization," the hallmark of the secularists, is not acceptable within a secular environment, but only in an Islamic framework, since the Islamist project embraces all aspects of life. ${ }^{40}$ Therefore, in his view, Islam, in order to avoid losing its own integrity, has to "penetrate" (ikhtiraq) modernity rather than the other way around. ${ }^{41}$ His critique of secularism is not unique to the Islamist project. It is common among liberal Western intellectuals and activists who advocate religious participation in public life in their own countries while at the same time rejecting the presence of religion in the state. ${ }^{42}$ However, Ghannouchi's project is not that of a liberal critique of secularism. Ghannouchi does not envision, in a future Tunisian democracy, a separation of religion and state: in the very words of Article 1 of the 1959 Constitution, Islam is for him and for his movement "the religion of the state." The Islamist movement argues for religious establishment and democracy, a combination 
that has perhaps gained more appeal for the movement with Ghannouchi's long exile in Great Britain.

Therefore, for al-Nahdha, the liberation of Islam from the control of the state does not mean the separation of state and religion, or even neutrality of the state towards religion. The state that Ghannouchi envisions is a civil and democratic state, but it also needs to engage with religion in specific ways: to organize it, but also, to implement it. Ghannouchi's liberation of Islam from the state does not imply a rupture between them. Rather, the state is put at the service of religion, and it is up to those democratically elected to govern and define the ways in which this "service" operates. It is striking that Ghannouchi does not talk of "sharia implementation" (tatbiq al-shari' $a$, a phrase widely used by other Islamist movements), but rather of "Islamic implementation" (tatbiq islami), a concept on which he does not elaborate. ${ }^{43}$ In addition, the relationship between state and religion remains ambivalent in the thought of al-Nahdha's activists. On the one hand, they clearly articulate a desire to liberate religion from state domination: the first issues of their weekly journal al-Fajr contained several articles demanding "the liberation of the mosques." ${ }^{44}$ On the other hand, they also insist that the state must organize (tanzim) religion without controlling it. ${ }^{45}$

Although the critique of state monopolization of religious institutions is central in the writings of al-Nahdha activists, it does not lead them to deepen their reflections about the legitimacy and the practical operations of a religious establishment: How would their party, heading the next government, make the state "Muslim"? This is the precise challenge that the Islamist movements in the Middle East overall have encountered after coming to power in the context of the Arab uprisings of 2010-2011: how to govern with reference to Islam and its values within the structure of a post-colonial state that originally made religion its own province and at 
the same time had the project to inculcate secular values to its subjects. A deep tension exists in the Islamist project between liberating Islam from the state's control and its enterprises of domestication on the one hand, and policy making based on religious values (nizam mina'lqiyam) on the other hand. ${ }^{46}$ It is, I want to suggest, this deep tension that makes the Islamists/secularists debate focus on ways of life rather than on ideologies and on the nature of the state. As Ghannouchi said in a public conference in March 2012, "The primary orbit for religion is not the state's apparatuses, but rather individual and personal convictions." ${ }^{47}$ The grand narrative of the Islamic state as the institution implementing sharia law is not part of Ghannouchi's discourse. His confident vision of a Tunisian society that has experienced a religious revival in the last decades also makes the use of the state to that end unnecessary: "we do not need to impose Islam because it is the people's religion and not the elite's, and Islam has not endured for so long because of states' influence, but rather due to the large acceptance it enjoys among its adherents, in fact the state has often been a burden on religion."

I will now reflect on the notion of secularism as it is understood by the Islamist party and examine how the opposition between "Islamism" and "secularism" translates at the political level.

\section{The Power of Labels: Laïcité, Modernity, and Islam.}

\section{Two Competing "Ways of Life"}

After the October 23, 2011 elections, secular parties on the left and other civil organization groups anxiously commented on the sudden emergence of the Islamist party at the center of Tunisia's political game: they accepted the ballot box results, but they were deeply worried about the future of "secular" Tunisia. When they spoke of secularism, they often used the French 
concept of laïcité. More specifically, some worried about the future of women's and individual rights. During and after the electoral campaign, the political and intellectual landscapes were polarized between the Islamists and their adversaries, who called themselves the "modernists," "the progressives," or the "secularists," and who denied the Islamists the "modernist" and "progressive" labels. These labels where inherited from the authoritarian regime, and continued to operate as political identifiers in everyday political life after January 14, 2011. Under the regime of Presidents Bourguiba and Ben Ali, official narratives described Islamism as the antithesis of "modernity" and "progress." The civil war developing in neighboring Algeria between the Islamist armed groups and the military and the consequences of 9/11 and "the war on terror" helped the Tunisian regime portray Islamism as a threat to civil peace and present itself as the best shield against it. In the official narratives, Islamism put into question the "modern" ways of life of Tunisians and particularly women's rights. ${ }^{49}$ It was striking that after January 2011, the opposition between the Islamist project and their opponents' understanding of their own model of society reflected a dichotomy between two "ways of life" rather than two systematically defined political ideologies and theoretical models for the state. Ahmed Ibrahim, leader of the Tajdid party (previously the Tunisian Communist Party), stated in October 2011, "Today in Tunisia, there is a modernist trend that seeks to reinforce freedoms and progressive values... There is another trend that wants to use the people's religious sentiments and attempts to impose a certain control and a very specific way of life." ${ }^{, 50}$ These ways of life were often described by referring to bodily practices. Ben Ali's regime in its fight against Islamists took aim at bodily practices, as shown by the earlier crystallization of the "Islamist/secularist" debate around the wearing of hijab, which Ben Ali's regime took pains to repress. ${ }^{51}$ This focus on body conduct-in particular questions of dress and diet-became even more explicit after the protests of 
2010-2011. Ajmi Lourimi, a member of al-Nahdha's leadership, described these two camps to me in the following terms, "The Islamist movements are afraid for Islam, and the secularists are afraid of Islam. And the secularists are afraid for their own individual way of life. They are afraid for their own individual rights. This is not about political rights, or citizenship rights, or religious rights. They are afraid not to be able to buy their wine at the café, not to be able to dress the way they want. ${ }^{, 52}$ This understanding gives us a clue to the nature of politics in post-Ben Ali Tunisia. Indeed, Ajmi Lourimi recognized that there was an agreement between all Tunisians on the principles of a democratic state, but that there was a need for a "new political culture" that would accept religion in the public space. He added: "Who dominates? The secularists. Those who oppose religion and want to eliminate it from the life of society...We demand a civil state, with institutions, and an independent justice system. Legitimacy comes from the ballot box. We demand political alternation, the respect of minorities' rights, and the defense of the principle of tolerance of the other. When we talk about a civil state, we do not mean a theocratic state. We want separation and balance between powers...And a press that is independent... We agree on the broad principles, on the basic principles that Islamists, liberals, secularists believe in: individual liberties, equality between all citizens. Are these principles the essence of secularism? No, these are the values of all children of Tunisia. Islam can work within these values. In addition, we have to revive the mosques, and the mosque pulpits, which must not be a space for political struggle, but for worship: they do not belong to political parties." ${ }^{, 53}$

For Ajmi Lourimi, as well as for the rest of the political spectrum, politics was not defined around ideological conceptions referring to well defined philosophical systems, such as those traditionally produced by the left side of the political spectrum or as the systematic constructions elaborated by the classic thinkers of political Islam-Abu al-Alaa al-Mawdudi or 
Sayyid Qutb, for instance. It revolved instead around 1) political procedures and 2) competing understandings of ways of life. Politics was defined around interrogations inherent to belief and conduct, rather than around "models" or blueprints for a social and political order. Rather than these "ways of life" deriving from theoretical considerations about political systems and theories of the state, they defined the essence of the political understandings represented by "Islamism" and "secularism." In post-Ben Ali Tunisia, political actors, intellectuals, and ordinary citizens argued about the ways of life they wanted, fearing that one camp would impose its own way of life on the other. None of them had a political theory to defend or a conceptual edifice to refer to, but they had models of life to propose. Yadh Ben Achour, a high profile legal scholar commented on the dichotomy opposing the Islamists and the secularists in the following way, "The Islamists are in a tight spot between their basic convictions and religious law on the one hand, and the enormous pressure that is exerted on them on the other hand: the pressure of modern ideas, of the International conventions for instance. They reject this pressure, the pressure of modern legal philosophy. Therefore, they become vague. All depends on the context in which they communicate. All depends on the climate. It is a contextual party. ...They are trapped in their contradictions. The Islamists are torn. They would like to live in their terrestrial city like in the time of the prophet, following the model of Madina. On the other hand, they have a world in front of them that is resisting: women wearing bikinis and the heavy drinkers. Tunisians are good believers who do not like constraints. ${ }^{\text {} 54}$ It is striking that both Ajmi Lourimi and Yadh Ben Achour defined the secularist and the Islamist projects as exclusively focused on ways of life respectively related to irreconcilable bodily practices.

Thinking about Labels 
Can these labels of "Islamism" and "secularism" help us describe the political landscape of postBen Ali Tunisia? The previous regimes instrumentalized them in order to divide and weaken the opposition, which compels us to use them carefully. However, these labels and the ways in which they have been elaborated play an important role and have a complex genealogy that has not been examined in detail yet. Their meanings are highly contentious. They do not encompass the totality of the political landscape. Those who are called "secularists" in particular, be they active in political parties or in civil society organizations, do not all necessarily center their platforms and ideas on secularism per se. Even though, for instance, the Pôle Démocratique Moderniste (PDM) focused its political campaign on an anti-Islamist agenda and on the values of secularism, this was not the case of the center-left party who obtained the best score after alNahdha-the Congrès pour la République (CPR). This party has accepted to govern in a coalition with the Islamist party after the October $23^{\text {rd }}$ election. The CPR's ex-leader and president of the interim government, Moncef Marzouki, is an intransigent defender of individual freedoms and human rights, who was president of the Tunisian Human Rights League between 1989 and 1992. He progressively became closer to the Islamist party, and started to include marked references to Islam in his political narratives. ${ }^{55}$ This means that he attempted to destabilize the secularist/Islamist dichotomy by ignoring it. The governmental coalition formed after the October 23, 2011 elections, or "troika," uniting al-Nahdha, the CPR, and Ettakatol also demonstrated the willingness of part of the left to collaborate with al-Nahdha in the government. Other parties that had worked with al-Nahdha in the October 18, 2005 alliance, such as the Parti Démocratique Progressiste (PDP), remained in the opposition and distanced themselves from and became more critical of the Islamist party. However, the political forces that did not belong to the constellation of Islamist parties created after January 2011 were often considered by the latter 
as "secularists," and sometimes as "the party of France," or hizb Faransa. The efforts to define politics outside of this dichotomy did not succeed. It is therefore worth examining how Islamist activists and intellectuals, in the liberalized transitional context, described the secularists. Indeed, even though the Islamists themselves are the object of numerous academic and political studies, scholarly work pays little attention to the Islamist narratives on secularism and secularists. In a country where the authoritarian state attempted to inculcate secular values to its subjects, the Islamists" representation of "secularism" merits examination.

In the second issue of the weekly al-Nahdha party's journal al-Fajr dated April 16, 2011, Shawqi Bu'anani, a Tunisian academic, published a piece titled "The Constitution between the Islamists and the Secularists. ${ }^{, 56} \mathrm{He}$ developed an analysis of secularism and secularists that implicitly reappropriated the tropes usually used in academic and political writings on Islamism. For him, it was a mistake to think that the Tunisian protests had nothing to do with the question of secularism. It was, he argued, "a political problem" that divided the political landscape in two camps, and even two classes (tabaqatayn). He continued that there were two sorts of secularism: the first, which he accepted, separated the state and the religious institution ${ }^{57}$; the second was "radical" and sought to eliminate religion from the public space and from life altogether. For

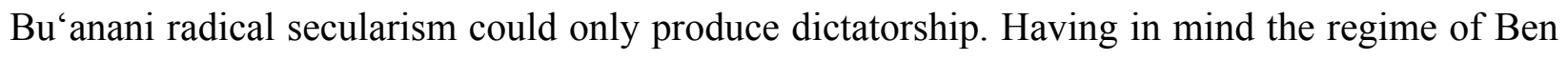
Ali, he also associated radical forms of secularism with the models of radical secularism of Nazi Germany, the Soviet Union, and France. For him, these cases exemplified radical secularism ('ilmaniyya mutatarrifa) because their secularism was "comprehensive" (shamila); radical secularism "separates religion from the life of the Muslim. We refuse secularism as a philosophy and an order (nizam) for life. We think that this type of secularism contradicts the intentions of our noble Islamic religion. ${ }^{, 58}$ The article operated as the mirror image of a series of arguments 
typically produced about Islamism by secularists and which go like this: in spite of the protests not being about Islam, it is important to deal with the question of Islamism as a "potential political problem." Islamism itself has many shades: radical Islam cannot combine with democracy and is therefore unacceptable, because it considers Islam as the foundation for a "comprehensive" order. This representation of secularism as having a plurality of possible meanings also led Ghannouchi to favor secularism as "a procedure" that makes the state, in a position of neutrality, guarantee freedoms and in particular religious freedom, over secularism as a "Jacobin model" or a "separation [between state and religion] in the French sense" of an "atheist philosophy" that excludes religion from the public realm. ${ }^{59}$ Therefore, Ghannouchi accepts secularism as a specific set of procedures that would allow different ways of life to develop and, perhaps, compete, but does not accept it as a "philosophy," that is as what could become the foundation of a way a life he disapproves of. However, this perspective is not accepted by all of al-Nahdha's leadership, who, for the more conservative part, is not ready to accept neither procedural nor substantive secularism.

The Imagined Sociology of Secularism and Islamism:

In addition to the description of the ideas behind Islamism and secularism by each camp, an imagined sociology of one another's constituencies also circulated. As early as Spring 2011, the ideological polarization between the "Islamist" and the "secularist" camps was playing out in a public debate, and the "Islamist" and "secularist" categories were endowed with a significant political role. The two "camps" built up a representation of each other through a mirror effect that distorted a complex reality by stereotyping it. However, the stereotypes themselves are not to be dismissed, They have a significant impact on the political arena. Indeed, they help describe 
the other side, as well as mobilize recruits for one's own camp. These descriptions are certainly different from what a rigorous sociology of party constituencies would reveal.

Indeed, in the political imagination of Tunisians, these two camps are represented by one another as being separated by language, culture, and class membership, and therefore as embodying competing ways of life. The secularist camp is often seen by the Islamists as Francophone and imbued with the values of French laïcité, as part of the old establishment of the post-colonial political and intellectual elites, and therefore as the ally of the authoritarian regime. Rached Ghannouchi explicitly equated laïcité with Ben Ali's regime in a speech he gave on secularism in Tunis on March 12, 2012, to an audience where many representatives of the secularist intelligentsia were present: "The stripping of the state from religion would turn the state into a mafia. ${ }^{60}$ The secularist camp is also represented as mimicking Westernized ways of life. The Islamists, on the other hand, are represented by the secularists as coming from a larger and perhaps more eclectic social spectrum. They are often portrayed as part of the Arabophone segments, of the lower urban middle classes as well as of poorer sections of society that define the identity of Tunisia along strict Arab and Muslim lines. It is said that they are particularly attuned to-and influenced by-the language of the Arab satellite television programs. This imagined sociology helps to anchor "Islamism" and "secularism" as political identities and constituencies and to reify each camp by grounding it into a post-colonial map that involves geographical, socio-economic, and cultural differences. Al-Nahdha is seen today as the party of the masses taking their revenge against the "Francophone" minority elite establishment and as being rooted in Oriental and Arab influences. The secularist parties are seen to represent more affluent segment of societies and to speak the language of the French episteme. However, this powerful imagined sociology is at odds with the real sociological lessons of the electoral results 
of October 2011 and only operates as the foundation of political arguments in the debate between secularists and Islamists. Indeed, the results of the election of October 23, 2011 show the same cleavages and same percentages in the French districts as in the Tunisian districts. This means that language is not a factor in explaining the electoral results since the Tunisian population that resides in France is mostly Francophone. In addition, al-Nahdha party was particularly strong in large urban centers, and did relatively poorly in the Center West region of Tunisia. It obtained its lowest score (14.30\%) in Sidi Bouzid, the cradle of the uprisings, and one of its highest scores of 40.64\% in Ben Arous, a poor and densely populated suburb of Tunis. Al-Nahdha's constituency seems to be as urban and as educated as that of the center left parties such as CPR and Ettakatol. In fact, none of the main secular or Islamist parties (CPR, Ettakatol, and al-Nahdha) won in Sidi Bouzid and Kasserine, two regions where social exclusion and poverty were the highest. A populist list, al-'aridha al-sha 'biyya, obtained $35.06 \%$ of the votes versus $1.55 \%$ for CPR, $0.97 \%$ for Ettakatol, and $14.30 \%$ for al-Nahdha. ${ }^{61}$ This seems to indicate that the secularist parties' and al-Nahdha's constituencies are not necessarily that different in terms of their socioeconomic characteristics. What seems to differentiate them more clearly is their understanding of cultural mores and identity politics, making al-Nahdha and secular parties defend two contrasting ways of life.

\section{Ways of Life as Limits to Freedoms}

Under the regimes of Bourguiba and Ben Ali, the state officialized the "modern" way of life: "feminist" and "westernized," as well as "authentically Tunisian." The authoritarian regime stigmatized and repressed the "Islamist" way of life. After the 2011 protests, these two camps confronted each other, using the tropes of the imagined sociology I described earlier. Sometimes 
they also initiated a dialogue in public forums. They were both free of the previous forms of direct and repressive censorship by the state, but were still constrained by these representations. They both came in defense of freedom, against the authoritarianism of the post-colonial regime, but they also both thought they needed to set limits to these freedoms in order to protect their ways of life in the new political competition that had opened up. The emergence of controversies helped shape these positions about limits to freedom. For instance, for the secularists, unlimited freedoms given to the Islamists were threatening "modernity," as happened when female students requested to be allowed in the university campus of La Mannouba University wearing a face veil at the end of the year 2011. For the Islamists, unlimited freedom of expression given to the "modernists" in the media was problematic. As an illustration of this tension, I will now examine a controversy that shows how the question of freedom of expression was being legally formulated in the period of political transition, and how some Islamists -who did not necessarily belong to al-Nahdha - referred to the notion of nizam 'amm or "public order" to confront their political adversaries in continuity with the legal narratives of the authoritarian regime.

\section{From Iran to Tunisia: the Persepolis Controversy in Court}

The Broadcast of Persepolis and the Public Order Argument

On October 7, 2011, the Maghrebi private television channel Nessma broadcast the movie Persepolis by Iranian film director Marjane Satrapi. The movie was dubbed in Tunisian dialect, in order to reach the largest possible audience. It was followed by a televised debate between four Tunisian intellectuals who discussed the movie in relation to the events taking place in Tunisia at that time. The debate was cast in the following terms: "will Tunisia be the next Iran?" Persepolis was the perfect setting for this debate, since it presented a critical view of the period 
of the Shah, whose dictatorship was compared to that of Ben Ali by the participants. It also spoke to the false hopes for democracy that the early coalition between the Islamists and the left had created in Iran before the takeover by the Mollahs. Nessma was clearly trying to build a parallel between the Iranian revolution of 1979 and the Tunisian political transition of 2011. The panelists around the table were all from the so called modernist trend, and no representative of the Islamist movement was present. They all confidently envisioned Tunisia in contrast with the Iranian model, underlining that modernism was so strong in Tunisian society that it could only prevail. Social networks such as Twitter and Facebook, as well as Tunisian, French and International news media announced afterwards that around "300 Salafis" had attempted to storm the offices of the television station and to attack its director, condemning scenes involving sex and alcohol in the movie, as well as a scene in which God is represented in human form. Contradictory reports subsequently claimed that the number of 300 protesters had been inflated and that the crowd did not consist of "Salafi" protestors exclusively. Doubt was also cast on the identity and the motives of the protestors and it was alleged that they might have been sent by those who wanted to derail the election scheduled for October 23, 2011.

\section{Public Order and the Limits to Freedoms}

More importantly for my purpose, the controversy took a legal turn transferring the political contentions that had taken place in the streets and on the social networks to the sphere of litigation: a collective of 144 lawyers acted as the plaintiff against the TV station CEO, Nabil Karoui. This collective claimed that Karoui had offended the "sacred values of Islam," as well as "decency." ${ }^{62}$ Karoui defended his actions by saying that the movie had been shown in theaters earlier in Tunis and that it had passed the scrutiny of the offices of state censorship. It was 
retorted to him that to show a movie in theaters had a lesser impact than to broadcast it on television.Movie theaters only gave access to the film to a small audience, but television made it enter into all Tunisian homes. The lawyers' collective based its complaint on two legal texts: the Press Code of 1975, a law that had been passed under President Bourguiba who had been appointed "President for Life" a year earlier. ${ }^{63}$ They referred to Articles 42 and 48 in particular. Article 42 states that "the accomplices of a crime or a misdemeanor will be punished if through the press or any other intentional mode of dissemination, they will have directly provoked (yuharridhuna mubasharatan shakhsan aw ashkhas) the author or the authors of a crime, and if the provocation "had an effect." Article 48 states that "belittling the dignity (nayl min karama) of an authorized religion" is also part of the offenses taken into account in Article 42. They also relied on the Penal Code, in which Article 226 penalizes "obscenity" (fuhsh) and Article 226a penalizes offenses against public decency (al-akhlaq al-hamida, a direct translation of the French "bonne moeurs") and public morality (al-adab al-'amma). The complaint brought to the court did not focus on a theological argument, but rather on a legal one. During the November $17^{\text {th }}$ audience of the court of first instance in Tunis, the Judge almost exclusively focused on the question of "complicity" of Karoui, asking if the film itself was at the origin of the protests and of the violent actions that followed, rather than if Nessma had the legal right to show the movie. Karoui insisted that the protestors had been provoked by political actors who had incited them into the streets and not by the movie itself. The argument of his accusers was that it was the showing of the movie that was the culprit. ${ }^{64}$ Karoui, they said, should have anticipated the effects of such a movie on the Tunisian population. According to them, the offense was about the disturbance of "public order" by the showing of the film rather than about the movie's depiction of Islam. Indeed, Article 48 of the Tunisian Press Code, which evokes the offense to the dignity 
of an authorized religion, belongs to a Chapter of the 1975 Press Code titled "Offenses Against Public Order" (junah murtakaba dhidd al-nizam al- 'amm). It is worth underlining that Tunisian law-as does French law, which influenced it significantly-often associates religion and religious freedom with the notion of public order. In the 1959 Tunisian constitution, freedom of belief was limited by the necessity to protect "public order," or al-nizam al- 'amm. In French law, the notion of public order has multiple meanings because, as underlined by Didier Bodin, it is used in different branches of law, ${ }^{65}$ such as criminal law, administrative law, and international private law. The exception "of public order" is invoked in French international private law when foreign law is not taken into account in national courts' processes of adjudication involving foreigners. ${ }^{66}$ The same exception is used in Tunisian international private law. ${ }^{67}$ When the discrepancy between two legal regimes is too important, the private law from the other state does not apply, because the foreign norm "harms" public order. As analyzed by Bodin, "International public order defines the limits of tolerance of our juridical system vis-à-vis foreign institutions." 68 However, in French law, the notion of public order is not restricted to International private law. In administrative law, itself a branch of public law, the notion of public order means "public security" (sécurité publique), that is "security, tranquility, salubrity, or public morality."69 It is in this sense that the 1905 French law of separation of church and state intends the notion of public order, and defines it as the limit to the tolerance of religious freedom. As in international private law, the notion of public order is connected with what a society can tolerate, that is what it can accept even if it does not approve. However, the administrative meaning of the notion of public order makes the physical implications of the threats to public order-that is the possibility of disorder and agitation that would make individuals and society physically vulnerable-more manifest. Article 5 of the Tunisian 1959 Constitution states that "the Tunisian Republic 
guarantees the inviolability of the human person and freedom of conscience, and protects the free exercise of religion, as long as it does not disturb the public order." This article, which mirrors Article 48 of the Press Code, may therefore be used to curb religious freedom.

For the Islamists, who associated in the collective of lawyers against Nessma TV, the notion of public order became the legal concept through which it was possible to make their claims against an unrestrained freedom of expression. Like the state, they understood the notion of freedom to be limited by the intolerance of the Tunisian public for specific cultural forms, an intolerance measured by the physical violence provoked by the showing of the movie.

The recourse to the legal structures of the authoritarian state shows that the Islamists were acting in a legalistic way and that, more importantly, they were formulating their claim through the rule of exception related to the notion of public order, that very public order that had limited their own freedom of religious practice and expression under the authoritarian regime. As analyzed by Hussein Agrama, the notion of public order is indeed a key tool for organizing religion and freedom of expression as objects of regulation and control by the state ${ }^{70}$. Although "secularists" and "Islamists" compete aggressively at the political level, they both belong to and accept a regime that regulates freedom through the legal exception of public order. Their contrasting visions of ideal ways of life mold themselves in the structures of the same old postcolonial state. They envision the new political life of Tunisia as a set of procedures that have no political meaning-i.e. that are not based on a philosophy or political theory that one would refer to when trying to make sense of these procedures-and that exist to protect each way of life against the other.

\section{Conclusion: A State Left Unchanged?}


At the end of March 2012, when debates were raging about the mention of sharia as a source for legislation in the constitution, Rached al-Ghannouchi declared that al-Nahdha would not ask for its inclusion. His declaration put an end to some of the tensions between Islamists and secularists, and provoked disappointments and critiques within his own camp. Some in the secularist camp claimed "victory." There was certainly a desire on the part of Ghannouchi to reach a compromise. However, he also understood that Article 1 of the 1959 Constitution was sufficient to make Islam the foundation of a way of life in Tunisia. Indeed, since sharia was to be defined through parliamentary legislation for him, its marked presence in the constitution was not necessary, perhaps without any effect, and therefore only symbolic. After all, since 1959, Islam was explicitly mentioned in the constitution and this did not prevent the repression of the Islamist movement. In the end, he thought Islam had to be embodied and practiced rather than theorized and mentioned in the constitutional narrative.

Indeed, the current leadership of al-Nahdha never provided a clear theory of the state, and did not seem to reflect on what Islamic governance meant, even as it held the reins of power after October 2011. It is striking that, whereas Ghannouchi's narratives contained deep critiques of the state at the time when he opposed it, al-Nahdha now accepted it, did not seek to radically transform it, and molded itself quite comfortably in its pre-existing structures. For its leadership, Islam defines principles for individuals' public conduct, and these principles must be protected, as guaranteed by the 1975 Press Law and by the current penal code.

Since Fall 2011, several other affairs have also erupted that have focused on the limits that religion can set to freedom of expression. The Persepolis controversy ended up with the public prosecutor fining Nabil Karoui 2,400 Tunisian Dinars (approximately \$1,530) on May 3, 2012, for "trouble against public order." The charge of the offense against religion and public 
morality was dismissed by the Judge, who perhaps had opted for a middle ground stance. Perhaps worried about the political repercussions of the affair, as the trial was ending al-Nahdha officially announced that the Persepolis case should not have been brought to court, and that a trial against Karoui "was not the best solution to solve the conflict between on the one hand the people's identity and the attachment to the sacred, and on the other hand freedom of expression."71 Other similar affairs developed in the course of 2012, in which freedom of expression was constrained by a justice decision. In these cases, the plaintiffs were individuals or groups who were often close to the Islamist movements or hailed from the nebulous Salafist trend. On March 28, 2012, two young men who published caricatures of the prophet Muhammad on the social networks were sentenced to 7 years of prison by the Mahdia correctional court for “disseminating publications disturbing public order" and "offense to morality." The complaint against the two young men was brought to court by a lawyer who denounced their atheism and was barely covered by the Tunisian and foreign media. ${ }^{72}$ On March 8,2012 , the Director of the journal Attounsia was sentenced to pay a fine of 1,000 Tunisian Dinars (approximately \$640) for having published on the journal's cover the photograph of a naked woman. On June 11, 2012, the artists exhibiting their works in the hall of the Abdelliyya Palace in the suburbs of La Marsa, saw a court bailif ask them to remove pictures considered by some Salafists as "blasphemous." After the artists refused to let the bailif in, the exhibit was attacked by Salafists who destroyed some of the art works. The self-proclaimed imam of the Zaytuna Mosque, Houcine Laabidi, called for the artists' murder. On August 17, two artists who were part of the exhibit were brought to justice by the tribunal of first instance of Tunis for "disturbing public order and offending decency." The affair mobilized civil society groups in defense of the artists, leading to the minister of culture-Mehdi Mabrouk, an independent-changing his mind about the merits of 
the exhibit. He had declared at first that it was mediocre and did not warrant to be defended, but eventually concluded that it had to be defended in the name of freedom of expression.

In all these affairs, which seriously compromise a freedom of expression only gained after the 2010-11 protests, the Troika government and al-Nahdha in particular have taken ambivalent positions, or have avoided taking a clear one, creating tensions within the governing coalition and beyond. Al-Nahdha seems to be drawn by its right wing and the Salafi constituencies into an uncompromising position to defend "sacred values" at the expense of freedom of expression. In addition, some of its members have also drawn the public debate toward conservative understandings of social mores and limits to freedom of expression in two legislative proposals presented to the Constituent Assembly. On August 1, 2012, the Committee for Rights and Liberties in the Assembly voted a constitutional article defining the "principle of [the] complementarity of women and men within the family," which was defended by al-Nahdha female member and vice president of the Assembly Maherzia Laabidi. However, after two months of intense debates outside of the Assembly, the committee dropped the article. Samir Dilou, member of the Troika and of the al-Nahdha party, declared on September 21, 2012 that the notion of complementarity "had no meaning."73 In the same vein, as a response to the Abdelliya controversy, on August $1^{\text {st }}, 2012$, the al-Nahdha group in the Constituent Assembly presented a draft law to amend the penal code so that that it would criminalize offenses against "sacred values" and "symbols." The project was eventually withdrawn after the strong opposition of civil society groups.

These affairs show that the two principles of Islam's protection and freedom of expression are now being pitted against each other, giving shape to cultural wars that will frame the politics of Tunisia for a long time. They are replacing the old debate between the "secular 
state" and the "Islamic state," and seem to thrive in the framework of the institutions of the old regime. Although al-Nahdha attempted to modify the law to provide more protection to Islamic values and a more Islamic veneer to the notion of "public order," the current laws already provide such a protection and are being used effectively to stifle freedom of expression. AlNahdha is not the only actor to use these laws. Salafis, as well as Islamist lawyers, have used them as political devices, and other constituencies in the future will surely use the public order exception to shape the public space in the way they see fit. A party such as Nida Tunis, which was formed in the summer of 2012 to counter al-Nahdha on a modernist platform, might also use the same exception if it comes to power. While these affairs follow one another and competing representations of ways of life overwhelm the public debates in Tunisia, and while political forces actively prepare for future elections, little attention is given to economic reform and to the foundations of the democratic state. For these reasons, the authoritarian state founded by Bourguiba and reappropriated by Ben Ali might very well endure under a democratically elected government.

I want to thank Benoît Challand, Tamir Moustafa, Kristen Stilt, Lucette Valensi, and two anonymous reviewers for their insightful comments on earlier drafts of this paper, as well as Youssef Ben Ismail for his research assistance.

${ }^{1}$ The period of mass protests that started on December 17, 2010-the day of the self-immolation of Mohamed Bouazizi-and ended on January 14, 2011-the departure of President Ben Ali from the country-was called a thawra by Tunisians, which can be translated by "uprising," "revolt," or "revolution." In its current usage, the word thawra often refers to revolutions of modern times such as the French revolution of 1789 or the revolt of Tunisians against the Bey's taxation policies in 1864. However, as I write these lines, it is too early to say if a revolution in the sense of a profound transformation of the state and of the socio-economic structures will take place as a consequence of the protests of 2010-2011. The state structures, the police, and the army, as well as the economic structures, have remained largely unchanged as I write these lines. For a widely accepted definition of social revolutions, see Theda Scokpol, States and Social Revolutions: A Comparative Analysis of France, Russia, and China (New York and Cambridge: Cambridge University Press, 1979).

${ }^{2}$ Sheldon Wolin, "Fugitive Democracy," Constellations, Volume 1, (1994), 1. I am thankful to Roxanne Euben for having mentioned this text to me.

3 "Go away" in colloquial French, or "beat it."

${ }^{4}$ The noun "people" in Arabic, $a l$-sha ' $b$, is a singular, contrary to its usage in English. The notion of a people represents a singular actor.

${ }^{5}$ A student who participated in the protests in Tunis before and after the fall of President Ben Ali, interviewed by the author, Tunis June 14, 2011. 


\footnotetext{
${ }^{6}$ The decrees published in the Journal Officiel (al-ra'id al-rasmi) after January 14, 2011 that reorganized some of the former regime's institutions often mentioned the revolution as defining a new era and new values for Tunisian law. To give only one example, the preamble of Decree 14-2011 of March 23, 2011, defining the temporary laws for the operations of the state (organisation des pouvoirs publics), mentioned that "in the revolution of January 14, 2011, the people expressed their will to exercise their total sovereignty in the framework of a new constitution." ${ }^{7}$ Ajmi Lourimi, interviewed by the author, Tunis, June 9, 2011.

${ }^{8}$ Ajmi Lourimi described to me al-Nahdha's project to see mosque imams elected by the faithful. Ajmi Lourimi.

${ }^{9}$ A university professor who participated in the January 14, 2011 protests in Tunis, Tunis, June 10, 2011.

${ }^{10}$ A teacher of civil and religious education, interviewed by the author, Tunis, June 13, 2011.

${ }^{11}$ A member of the Maghrebi Liberal Party (PLM), interviewed by the author, Tunis, June 11, 2011.

${ }^{12}$ In Algeria, riots broke out in 1982 (Oran), in 1980 and in June 1988 (Kabylia), in 1986 (Constantine), and in October 1988 (Algiers). The riots of October 1988 led to the legislative elections of June 1991, their suspension by the military, and the ensuing civil war that lasted until 1998. In Morocco, riots occurred in 1965, 1981, 1984, and 1990. In Tunisia, popular unrest seemed less frequent: the two main protests that occurred in the history of postcolonial Tunisia are the general strike of January 1978 and the protests against price increases in January 1984. See Didier Le Saout et Marguerite Rollinde, Emeutes et mouvements sociaux au Maghreb, Perspective comparée (Paris, Khartala-Institut Maghreb-Europe, 1999).

${ }^{13}$ John Waterbury, "Fortuitous By-Products," Comparative Politics, 29 (3), (April 1997), 383-402. Ghassan Salamé, Democracy without Democrats. The Renewal of Politics in the Muslim World, (London: I.B. Tauris, 2001).

${ }^{14}$ Data from the World Bank, http://data.worldbank.org/ For instances of narratives about the economic miracle, see "Le miracle économique tunisien," L'économiste, no 254, 26 mai au 9 juin 2010. The article was written by Jean François Limantour, president of the Euro-mediterranean circle of the textile managers. More generally, the regime insisted on the political stability of Tunisia and on its good economic performance relative to the rest of the Maghreb region, leading to tensions with the World Bank in 2007, which criticized the regime's governance. For an analysis of the construction of the myth of the economic miracle by the Tunisian regime, see Beatrice Hibou, Hamza Meddeb, and Mohamed Hamdi, "La Tunisie d'après le 14 janvier et son économie politique et sociale," Fonds d'Analyse des Sociétés Politiques, Copenhague, (June 2011).

${ }^{15}$ International Monetary Fund, Regional Economic Outlook. Middle East and Central Aisa, 2011, p. 74. Growth is evaluated in purchasing power parity.

${ }^{16}$ The percentage of the population that considers itself "thriving" in Tunisia decreased from $24 \%$ in 2008 to $14 \%$ in 2010. Jon Clifton and Lymari Morales, "Egyptians', Tunisians' Wellbeing Plummets Despite GDP Gains," Gallup Report, (February 2, 2011)

${ }^{17}$ Hassen Boubakri, "Tunisie: Migrations, marché du travail et développement", Document de travail, Organisation Internationale du Travail (Institut International d'Etudes Sociales, 2010).

${ }^{18}$ International Monetary Fund, Regional Economic Outlook, (April 2011), 39.

${ }^{19}$ Binyamin Applebaum, "World Bank and I.M.F. Discuss Inequality in the Middle East," New York Times, April 15, 2011, p. B 3. Applebaum writes, "By focusing primarily on the country's growth, the World Bank and other international bodies failed to notice widening inequalities. Now, in the wake of a revolution still shaking the region, the World Bank says Tunisia can serve as a model for a revised approach."

${ }^{20}$ In Sidi Bouzid, the relative rate of poverty went from $39.8 \%$ in 1990 to $45.7 \%$ in 2000 . For more details on these figures in the different regions of Tunisia, see Sami Bibi and Vincent Casterl, "La pauvreté et l'inégalité en Tunisie, au Maroc et en Mauritanie," Note Economique, Banque Africaine de Développement, 2011.

${ }^{21}$ Bouazizi's self-immolation was not the first one to occur in Tunisia or the Maghreb. Usually, self-immolations did not turn into political events. In December 2010, it was politicized when local Trade Union representatives supported Bouazizi's and his family and helped mobilize protests.

${ }^{22}$ International Crisis Group, "Popular Protests in North African and the Middle East: Tunisia's Way," Report no 106, April 28, 2011.

${ }^{23}$ Malika Zeghal, “The Power of a New Political Imagination,” The Immanent Frame, February 22, 2011, http://blogs.ssrc.org/tif/2011/02/22/the-power-of-a-new-political-imagination/

${ }^{24}$ Michel Foucault, Histoire de la sexualité I, La Volonté de savoir (Paris, Gallimard), 25.

${ }^{25}$ In fact, the desire to marginalize Islam's significance made it even more present by making it an object of discourse.

${ }^{26}$ During the night of August 2, 1987, attacks in hotels in Monastir and Sousse (13 people injured) and, in February 1991, attacks in the Bab Souika's neighborhood in Tunis against an office of the party in power, the Constitutional Democratic Rally (RCD), in which one of the attendants was murdered, were attributed to al-Nahdha by the regime.
} 
The opposition accused the regime of having planned and executed these attacks in order to prepare a takeover of the state and consolidate its authoritarianism.

${ }^{27}$ See Rached Ghannouchi, Harakat al-ittijāh al-islāmī fì Tünis, (Kuwayt, Dar al-qalam, 1989). In particular, the book reproduces an article dating from 1983 entitled "Wujūd aw tajdīd?," 113-135, in which Ghannouchi explains the vagueness of the movement's program by the fact that the absence of democracy in Tunisia and the semiclandestine character of the movement made it impossible to produce and discuss a clear program.

${ }^{28}$ Ghannouchi, Harakāt, 122-123.

${ }^{29}$ Ahmad S. Moussali, "Modern Islamic Fundamentalist Discourses on Civil Society, Pluralism and Democracy," in Civil Society in the Middle East, ed. Augustus R. Norton (Leiden \& New York: E.J. Brill, 1995), 79-119; R.

Ghannouchi ‘Traditional Muslim Society is a Model of Civil Society', in Islam and Secularism In The Middle East, ed. A. Tamimi and J. Esposito (London: Hurst and Company, 2000).

${ }^{30}$ Vincent Geisser et Moncef Marzouki, Dictateurs en sursis, une voie démocratique pour le monde arabe (Paris, Editions de l'Atelier, 2009), 31.

${ }^{31}$ The existence and nature of this alliance is an object of contention among its members.

32 Janine A. Clark has shown that collaboration of Jordanian Islamist parties with the rest of the opposition could lead them to moderate their position on some points: Janine A. Clark, "The Conditions of Islamist Moderation. Unpacking Cross-Ideological Collaboration in Jordan," International Journal of Middle East Studies, Vol 38, No 4, (Nov. 2006), 539-560.

${ }^{33}$ For instance, Rached Ghannouchi, al-haraka al-islämiyya wa mas'alat al-targhyìr, (London, Maghreb Center for Researches and Translation, 2000).

${ }^{34}$ See for instance Rached Gannouchi, Conference on Secularism, Tunis, March 2, 2012, Center for the Study of Islam and Democracy: "The nation-umma-is the only manifestation of divine will through its interactions and not any particular scholar, party, or state" http://blog.sami-aldeeb.com/2012/03/09/full-transcript-of-rached-

ghannouchis-lecture-on-secularism-march-2-2012/ Accessed April 2, 2012.

${ }_{35}^{35}$ A previous minister of Bourguiba, interviewed by the author, Tunis, June 14, 2011.

${ }^{36}$ Fawzia Charfi, interviewed by the author, Tunis, June 18, 2011.

${ }^{37}$ Ajmi Lourimi.

${ }^{38}$ Rached Ghannouchi, "Is the Islamist movement's project retreating?" in al-haraka al-islāmiyya, ru'ya naqdiyya, al-intishār al- 'arabī, ed. Mustapha al-Habbab (Beyrout, 2011), 36-37.

${ }^{39}$ Ibid, 36-37.

${ }^{40}$ Ibid, 37.

${ }^{41}$ Ibid, 37.

${ }^{42}$ See for instance, Jose Casanova, Public Religions in the Modern World, Chicago, The University of Chicago Press, 1996, especially the conclusion.

${ }^{43}$ Ghannouchi, "Is the Islamist movement's project retreating?" 32, 45.

${ }^{44}$ For instance, Muhammad Chadhili Bukhari, "Hatta la tatahawwala al-masajid ila qamis "uthman," Al-Fajr, no 3, April 22, 2011, p. 5.

${ }^{45}$ Ajmi Lourimi.

${ }^{46}$ Gannouchi, Conference on Secularism.

${ }^{47}$ Gannouchi, Conference on Secularism.

${ }^{48}$ Gannouchi, Conference on Secularism.

${ }^{49}$ Malika Zeghal, "Veiling and Unveiling Muslim Women: State Coercion, Islam, and the 'Disciplines of the Heart'," in Aziz Esmail and Abdou Filali-Ansary, eds., The Construction of Belief. Reflections on the Thought of Mohammed Arkoun, London, Saqi Books, 2012

${ }^{50}$ Ahmed Ibrahim, general secretary of the Etajdid movement (Pôle Démocratique Moderniste), L'express, 10/15/2011, http://www.lexpress.fr/actualites/2/monde/la-gauche-tunisienne-juge-que-les-islamistes-menacent-lalaicite 1041016.html accessed 4/2/2012.

${ }^{51}$ See for instance, Vincent Geisser et Éric Gobe, «La question de 1" "authenticité tunisienne" : valeur refuge d'un régime à bout de souffle », L'Année du Maghreb Édition 2007, Paris, CNRS Editions, 2007, p. 371- 408.

${ }_{53}^{52}$ Ajmi Lourimi. Emphasis is mine.

${ }^{53}$ Ajmi Lourimi.

${ }^{54}$ Yadh Ben Achour, interviewed by the author, La Marsa, June 11, 2011. Emphasis is mine.

${ }^{55}$ Moncef Marzouki, Dictateurs en Sursis. Une voie démocratique pour le monde arabe, Paris, Editions de l'Atelier, 2009 , chapter 3.

${ }^{56}$ Shawqi Bu'anani, "al-dustur bayna al-islamiyyin wa'l-'ilmaniyyin”, al-Fajr, (April 16, 2011), 20. 
${ }^{57}$ The paper does not give a definition of the religious institution.

${ }^{58} \mathrm{Bu}$ 'anani, 20.

${ }^{59}$ Gannouchi, Conference on Secularism, "We demonstrated that secularism is not an atheist philosophy but merely a set of procedural arrangements designed to safeguard the freedom of belief and thought."

${ }^{60}$ Gannouchi, Conference on Secularism.

${ }^{61}$ For the official results of October 23, 2011, see al-hay'a al-'ulyā li’l-intikhabāt, Taqrīr hawla sayr inthikhabāt almajlis al-watanī al-ta'sīsī, Tunis, February 2012.

${ }^{62}$ Complaint of 144 lawyers brought to the court of first instance of Tunis, October 10, 2011.

${ }^{63}$ Law no 1975-32 ("majallat al-sahafa") published in al-ra'id al-rasmi li'l-jumhuriyya al-tunisiyya, April 29, 1975, no. 29, p. 992-999. Article 42: "Seront punis, comme complices d'une action qualifiée de crime ou de délit selon les définitions prévues par les articles 43 et suivants, ceux qui, par voie de presse ou par tout autre mode intentionnel de propagation auront directement provoqué l'auteur ou les auteurs à commettre ladite action, si la provocation a été suivie d'effet."

${ }^{64}$ See the first session (November 17, 2011) of the trial on the following link http://www.nessma.tv/replay.php?508c75c8507a2ae5223dfd2faeb98122\&ep=279\&open=0

Accessed November 18, 2011.

${ }^{65}$ Didier Bodin, L'ordre public. Limite et condition de la tolérance. Recherches sur le pluralisme juridique. (Unpublished Dissertation, 2002), 2.

${ }^{66}$ Hussein Ali Agrama analyzes the meaning of public order in Egyptian law in "Secularism, Sovereignty, Indeterminacy: Is Egypt a Secular or a Religious State?” Comparative Studies in Society and History, v. 52(3), 1-29. Agrama describes the notion of public order as "central to the liberal rule of law." In contrast to his analysis, I see the French legal notion of "public order" as making possible an illiberal regulation of public life by the state, which is at the heart of the practices of the French state as well as of the Tunisian state. Whereas France legally separates state and religion and Tunisia legally makes Islam « the religion of the state », the two states use the legal notion of public order to regulate the definition and the place of religion in their societies in similar ways.

${ }^{67}$ See Code de Droit International Privé, République Tunisienne, Articles 26-38. In particular Article 36 "L'exception de l'ordre public ne peut être soulevée par le juge que lorsque les dispositions du droit étranger désigné s'opposent aux choix fondamentaux du système juridique tunisien." (loi 98-97 du 27 Novembre 1998 portant promulgation du code de droit international privé).

${ }^{68}$ Didier Bodin, L'ordre public. 2.

${ }^{69}$ Didier Bodin, L'ordre public, 66.

${ }^{70}$ Hussein Ali Agrama "Secularism, Sovereignty, Indeterminacy."

71 "Tunisie: Ennahda estime que le procès "Persepolis" n'est pas la solution," Le Monde, January 23, 2012. http:/www.lemonde.fr/tunisie/article/2012/01/23/tunisie-le-proces-persepolis-reporte-au-19avril_1633221_1466522.html accessed January 23, 2013.

${ }^{72} \mathrm{http}$ ://tobegoodagain.wordpress.com/2012/04/05/affaire-mahdia-lenquete-atheisme-delit-de-pensee-atteinte-ausacre/ accessed October 21, 2012.

${ }^{73}$ Samir Dilou, interview in L'Express, September 21, 2012. http://www.lexpress.fr/actualite/monde/afrique/tunisienous-avons-commis-des-erreurs 1162293.html accessed January 20, 2013.

Malika Zeghal is Prince Alwaleed Bin Talal Professor in Contemporary Islamic Thought and Life at Harvard University. She has published a study of central religious institutions in Egypt (Gardiens de l'Islam. Les oulémas d'al-Azhar dans l'Egypte contemporaine [Presses de Sciences Po, 1996]), and a volume on Islam and politics in Morocco (Islamism in Morocco: Religion, Authoritarianism, and Electoral Politics[Markus Wiener, 2008]. She is currently working on a book on states, secularity, and Islam in the contemporary Arab world, forthcoming at Princeton University Press. 